\title{
PRIVATE PROPERTY AND PUBLIC HEALTH REFORM IN ENGLAND 1830-70
}

\author{
GERRY KEARNS \\ Department of Geography, University of Liverpool, P.O. Box 147, Liverpool L69 3BX, England
}

\begin{abstract}
British cities of the mid-nineteenth century were insanitary. In many cases lack of street paving, insufficient water, proliferating cesspools and open sewers turned them into cloying, degrading and offensive mires. Many of the urban workers, too poor to pay rent sufficient to meet the costs of these environmental services, were shuffled among damp dingy rooms into which the sun shone feebly and in which their physical odours were confined against any draughts. The relations between landlord and tenant were circumscribed by the indebtedness of the former and the penury of the latter. Water, sewerage and housing standards were left to the sway of the market while the effective demand for them was limited by low real wages. In the largest cities this filth was dangerous as well as offensive and public health reforms became ever more pressing. Yet the form in which this legislation was secured and the manner in which it was implemented were not as straightforward as this sketch of their crying necessity might suggest.
\end{abstract}

In this paper, the English public health movement of the mid-nineteenth century is considered as part of two histories: the history of government growth and the history of environmentalist ideas. The emphasis here is on how these ideas were incorporated in coherent arguments for state intervention in the urban environment. Existing studies of public health reform document the main stages in the development of public concern and the extra-parliamentary pressure for legislation. It is widely recognised that public health reform took very great risks with the sanctity of property and that, as Henriques has written, "public intervention for health purposes meant intervention in the management of private property, since the seventeenth century the sacred cow of all sacred cows" [1]. It is also well established that in addition to the general opposition to restricting the free play of the market, there was a particular resentment that the rights of local property owners to manage their collective affairs in autonomous local authorities were being attacked. Bruce, for example, has noted that "there was much resistance to government interference in local affairs, even in such a matter as public health" [2]. Bruce referred to the parliamentary activity bounded by the Public Health Acts of 1848 and 1875 as "the period of environmental sanitary legislation" [2, p.11]. O'Riordan has claimed that "it is generally accepted that 'public health' is a major collective goal" and has even placed it second only to national security in a "hierarchy of national goals" [3]. Clearly, the enviromentalist public health movement must be counted as a great success. A society dedicated to the pursuit of private profit conceded the need to restrain the activities of urban property owners in the interest of more health living. Yet in the histories of public health reform this paradox is rarely met head on. How was it possible for reformers to square the circle of collectivism and private enterprise? We know today that the two have proved compatible but the Victorians experienced the contradiction as the yawning possibility of the demise of the ethics of the market. Failure to confront this question directly makes it impossible to accurately characterise the reforms that were achieved: did they aim to enable or replace private markets? The confusion extends to the proper characterisation of the role of the most important public health reformer of the age, Edwin Chadwick. Chadwick was the archetype of the new state servants, or bureaucrats, who staffed and animated government growth in the nineteenth century. Between 1834 and 1854 he was central to most state innovations in social policy. Portraying Chadwick as the fountain head of the welfare state, historians have been unsure where to place his brand of collectivism on a continuum running from capitalism to socialism. Given the importance of an accurate appreciation of the scope and limits of the modern state for modern politics and the common presentation of its commitments as a set of historicallyacquired responsibilities, this uncertainty is of more than academic significance.

This paper offers one perspective on this problem. It examines how arguments for enviromentalist public health policies were put together. It is suggested that these show a great sensitivity to precisely the paradox outlined above and that state intervention could be made compatible with private markets only at the cost of relating public health problems to market failure and thereby conceding that there were important sectors of the economy where the market could not be trusted to hold sway. The attack on private property was instead presented as an abstract defence of the virtues of free markets and the dangers of imperfect ones. This defence was placed within a broad cosmology emphasising the harmony between free markets, nature and mortality. Here, this is presented as an attempt by Chadwick to accumulate enough pertinent affirmations of his policy and avoid the crippling effects of running into relevant ideological sanctions of his policy. In this regard, theories of market behaviour, of disease and of government were all of a piece and became interdependent parts of the case for reform. Three themes are developed in the paper: that public health reforms restuctured property rights; that these rights structured the reforms to which they became subject; and that these 
reciprocal developments were basic to the growth of government. As statement of fact, all three themes are probably self-evident and the aim of the paper is to explore them and their significance rather than to show that they are true; the focus here is not on whether but on how. The paper is in four sections. In the first, the point is made that nineteenth-century public health reforms were environmental regulations which took the responsibilities of property as the proper focus of intervention. In the second, the way that property was the medium for sanitary activity is briefly described. In the third, the way that the case for reform negotiated the veto implied by the inviolable rights of property is explored. Finally, the ideological sway of private property is considered as an aspect of its political dominance.

\section{ENVIRONMENTALISM AND SOCIAL RESPONSIBILITY}

The environmentalism of nineteenth-century social thought is widely recognised. Malthus drew attention to the biological basis of society and, despite the ideological sway of the economics of pure competition, there proved to be no going back on this finding. As biological phenomena, people were clearly influenced by their environments. Buckle wrote of the environmentalist influences on religion with superstitious Catholics living in the frightening vulcanic Mediterranean lands and cool rational Protestants living on the tectonically more stable north European plain [4]. This line of reasoning was so pervasive that all sorts of issues became 'environmentalised' allowing people, for example, to seek architectural solutions to moral problems. Public health reform was clearly an environmental issue in the strongest sense. The regulation of the environment, here, meant controlling property as opposed to controlling people. This is in clear contrast to a public health strategy based principally on controlling the movement of people through quarantine. The emphasis was on places not people. The plague was shut out in the sixteenth and seventeenth-centuries whereas the seedbeds of cholera were cleaned up in the nineteenth. The contrast is not absolute since, of course, there was some, weak environmental regulation in sixteenth-century England and there were exclusionist principles behind the activities of the Port Sanitary Authorities during the later-nineteenthcentury [5]. Nevertheless there are significant differences of emphasis here. An environmentalist public health strategy based on controlling places meant, in a society where land was privately owned, extending the social responsibilities attaching to the ownership of urban property. These extensions were many and varied.

If we may speak of urban morbidity and mortality as the problem, then, the answer was to recognise a broader set of environmental responsibilities attaching to property. This was not an inevitable line of advance. Among the alternatives developed less strongly than this, there were attempts to deepen the legal responsibilities of the sick through various 'notifications of infectious diseases' Acts. This strategy was applied most aggressively in the case of socially or politically marginal groups such as in the attempt to control venereal disease by regulating prostilutes. In the main, though, the greatest attention was paid to the responsibilities of property. Landlords had their right to accept a fair price for an offered product tampered with. From the bye-laws of the 1840 s through to the rights of local boards of health under the 1848 Public Health Act to approve building plans, the quality of the product to be sold was regulated. And this at a time when the links between building costs, rents and wages were well recognised. Then, the rights of the house-owner to lease out his premises were subject to controls on the habitation of cellars, the degree of overcrowding allowed under the 1851 Lodging Houses Act and even, under the 1848 Public Health Act, the extent to which tenants could accept a service, with respect to drainage, sewerage and water supply, which might convert the property into a health hazard. Furthermore, certain specific land uses came under closer scrutiny with the driving out of towns of pigkeepers and cowkeepers, under the Nuisances Acts from 1846 , to say nothing of holding urban industries accountable to every twitching of the sanitary inspector's nose.

Some of these new responsibilities fell to the urban local authorities. The General Board of Health, under the 1848 Public Health Act, was empowered to permit local authorities to raise unheard of sums on the security of the rates in order to undertake drainage, sewerage or the provision of a municipal water supply. The Board was under an obligation to see first whether private enterprise might provide adequate services but these services could, then, by default, be developed under municipal ownership. Outside port cities, this was an unprecedented extension of municipal property-holding and was different in kind from the corporation-based control of the market place which made up the greater part of communal ownership in the early modern town. Furthermore, since these new properties were ultimately funded from rates raised on landed property within the town, they qualified those landed property rights. In the second half of the nineteenth-century the new urban properties in workhouses, schools, sewers and water companies brought in their train expectations and interest payments which made serious inroads into the viability of small landlordism, as Avner Offer shows [6], and set the stage for the economic and the political marginalisation of this group [7].

In an ecological sense, we might speak of the social control over the urban environment as an adaptive strategy, a means whereby society adjusted to the ecological pressures of large-scale city living. Yet the self-conscious nature of political developments entails that we specify how and why certain steps were taken. A small part of the answer lies in technology. Given a relatively wet climate, there is water available at reasonable cost to drive a water-closet based sewerage system. This sort of system requires some shared use of common facilities, such as sewers. The alternative is the more labour-intensive removal of sewage from cesspools or septic tanks. Even if, for economic and climatic reasons, the combined sewerage/drainage system was more suited to nineteenth-century towns, there still remains the task of 
explaining why they were financed in the way they were. It should be noted that the division between public goods and private goods is not a clear one. There is also the ideological damage done to private enterprise when it is suggested that certain services are not really suited to being placed on the same footing as all other forms of bourgeois property. Here again, there were, and continue to be, alternatives; from private water companies and commissions of sewers to publically owned but quasi-autonomous boards (like the former English Gas Boards) through to municipal services directly accountable to local councils. Accepting the case for some state direction in the field of public health left open a wide range of options with respect to the balance between public and private interests in financing, directing and providing these services.

What is striking about how urban authorities acquired property rights under public health legislation is that these powers were exercised by vestries or councils answerable to a propertied electorate and administered by a restricted ruling class. For logistical reasons, one might expect these sorts of social responsibilities to be discharged locally but to tie them to a property rate underlines the paradox of local autonomy without the democratic dilutions implied by the wider and more dynamic tax base on which central government drew, with its excise duties and, increasingly, its income taxes. The sort of government growth epitomised by public health reform qualified property rights by being based on a property tax and by attaching new responsibilities to the use and disposal of property. Inevitably, these sorts of changes in rights and responsibilities were subject to all sorts of class-based forces from the long battle within the towns over the municipal franchise to the guerilla war over the rates. Thus, as Brayshay and Pointon show, the case that civic authorities ought to be open to a broader section of property owners went hand in hand with the claim that the narrow basis of urban government led it to take too restricted a view of its social responsibilities [8]. An even wider section of property-owners consistently contested the assertion that sanitation was a matter for the rates. This, Chadwick's 'meanest class', while rarely effective in Parliament gnawed away at the pretensions of reforming urban governments and aimed to transfer their public health responsibilities towards the social purse and the central exchequer.

The sort of public health reforms that were imple. mented bore the impress of these class struggles both because they werc nurtured within political bodics which represented property and also because they surfaced in debates whose ground rules were based on property. The study of how propertied interests structured the public health reforms to which they were subject reveals both a political and an ideological component. After all, local rates, unlike for example national income tax, were a tax solely on property. They particularly affected the lower middle classes who held much of their wealth in this form. Local government was financed by and constituted by this particular class interest. Yet this was to be the vehicle of a public health policy focussing on the regulation of property and passing on the costs of improvements to the owners of property.

\section{THE POLITICS OF PROPERTY}

From the shareholders of the private London water companies who sat in Parliament and removed Chadwick from the General Board of Health in 1854 to the slum landlords who sat on vestries turning a blind eye to the sanitary conditions of their interests, there were a number of ways in which propertied interests could affect both the framing and the implementation of public health reforms. The aim of the legislators was to offend these parties as little as possible both because of their recognised control over the use of the law and because the legislators shared a general commitment to the rights of property. In general the responsibilities of property were held to be balanced by its rights of representation. Yet this operated quite unevenly both across different types of property and from place to place. The relations between public health strategies and the urban franchise need further study but along with the nature of the local economy it was probably a crucial control on the character and levels of sanitary activity. For Sheffield, Pollard showed that changes in the local franchise were related to shifts in the focus of sanitary activity with a broader franchise accompanying a more ambitious programme [9]. In many cases, the most dangerous properties were owned in the smallest units. So that where the authority consisted of a representative vestry and an executive board of trustees with a stricter property qualification for the latter, then, the division of responsibility between the two was an important determinant of the interference with property. In the London borough of Islington, for example, the primary control exercised by the vestry was in the setting of the rate. This held back any expensive capital projects such as drainage or sewerage but left scope for the Trustees to set up sanitary committees, in the period 1848-54, which policed the condition of individual small properties [10]. In other words, while we might expect Vigier to be right in suggesting that a broader franchise meant a more responsive authority with a more interventionist sanitary policy, we must nevertheless recognise that the rating system fell heaviest on those small property owners who were most likely to have the dangerous small businesses or the least wellmaintained houses [11]. There was, therefore, a political bottleneck in the property hierarchy which protected those above from higher rates and which saw the masses below as unpropertied and hence prone to make irresponsible claims on the municipal purse.

Representation as a corollary of the responsibility of property was not only unevenly distributed it also influenced the form in which rights were conceived. As Corrigan and Sayer argue, the extension of the political community in the nineteenth century was a sharing of power between landed and other forms of property. The rights of labour power were conceived in the same forms and labourers were urged to be individuals who could be treated "as if they had, or could someday possess, bourgeois properties individually without possessing profitable property" [12]; Labour power as a form of property might perhaps have been viewed as a common law right whose value could be defended against environmental dangers in much the same way as was supposedly available to 
holders of other sorts of property. Instead the protection of an individual's health was more frequently conceived in terms of insurance. The principles of insurance offered a way of measuring the social costs of sickness. Chadwick and Farr were both concerned with insurance before they wrote about public health questions. In eliding thus the distinction between personal and social insurance the gap was also closed between a person's right to health and society's right to healthy people. Labour power was a form of social property and the same basis on which other forms of property was guarded against accident could be cxtended to the national labour force. To this extent unhealthy cities carried with them an imputed insurance cost as far as this national property asset was concerned.

Property was represented, in various ways, on the agencies to whom the public health legislation was entrusted. Finally, of course, it was represented on the bench. During the tenure of the first General Board of Health, Ashley, a member of the Board, remarked ruefully to Chadwick, also a member, that "the magistrates are against us" [13]. In Islington, the local board of health found the same problem. In defining a nuisance the opinion of Queen's Council was that any court order applied only to the specific body of matter which was present at the time of the initial complaint. The point of law arose because of the delays involved in the local board of health seeking to enforce the provisions of the Nuisances Removal and Diseases Prevention Act against the owner of a dust-shoot. This delay, thought Mr Bodkin Q.C., meant that the original magistrate's order aginst the owner was no longer in force since "the matter removed must be the identical matter referred to by the order. It is now I apprehend impossible to show that the matter adjudicated upon on the 11 th February still remains, there may be similar matter emitting effusions equally offensive but this is not I think sufficient" [14]. This nice interpretation of the Act was singularly unhelpful. In addition local boards of health found the legal option expensive, cumbersome, tardy and uncertain. In Islington, in fact, the vigorous attempts of the board to punish the owners of filthy houses eventually foundered as magistrates interpreted the responsibilities of property as falling to those who had use of the property rather than those who owned it; a radical severance of responsibility and representation. This meant that if the board took upon itself to clean up properties which were certified to be dangerous but which the owners had been unwilling to amend, then the board would have to proceed against the poor tenants for compensation. The Trustees were appraised of the implications by their Highways Surveyor:

The above decision will in great measure paralyse any efforts for purifying the houses of the poor, for if the occupiers of such houses were to be selected as the amenable parties their poverty would prevent their complying with orders that might be made upon them and the consequences would be, that the execution of such orders would devolve upon your committee thus casting a heavy burden upon the parish funds. The propriety of continuing to call upon parties to cleanse houses remains in abeyance [14, 11 February 1849].

The cost and unworkability of the law was widely recognised as part of the defence of private propcrty.
In opposing the Nuisances Removal and Diseases Prevention Acts, one representative of the 'offensive trades' was "quite content that we should be left under the common law of England" feeling "a manufacturer who has embarked a large sum of money, ought to have the security which an expensive process to go through gives" [15]. In a similar vein, Joseph Heron, the Town Clerk of Manchester, took a narrow rather than a broad view of the responsibilities of property when he told a Select Committee: "I do not see why the owner should be made liable at all. In many cases the nuisances arise by the acts of the tenants, over whom he has no control" [15, q. 1506, p. 185].

The conception of rights to health, and the implementation and interpretation of public health legislation were based on the rights, responsibilities and representation of private property. Property was the medium of intervention. This was recognised by the advocates of public health reform and, in abstract terms, they wished to uphold the institution of private property. In this area, we find a set of political struggles within the propertied classes anticipated by the ideological manoeuvrings of the reformers. In this, Chadwick was immensely significant and while we may note the role of doctors and journalists in establishing a sympathy for reform, it really took a philosophical and legal disposition to establish its justice in the face of this propertied political nation.

\section{THE IDEOLOGY OF PROPERTY}

If the case for public health reform is seen as self-evident, then the activity of pressure groups becomes merely a sort of journalism. But to propose qualifying the rights of property, to take up the 'Condition of England Question' with a view to interfering with those rights and to apparently give credence to the claims of the unpropertied on the public purse was to shake principles central to the heroic self-image of the Victorian bourgeoisie. What Edwin Chadwick did between the mid-1830s and the mid-1840s was to argue a case for sanitary reform which, while consistent with some of the rationalisations of this self-image, was also likely to result in effective legislation. This was an intellectual rather than a journalistic achievement. Chadwick's arguments combined a theory of government, a sanitary idea' and an account of the relations between the social and natural worlds all of which celebrated the ethical and moral justifications for private property. As Flinn rightly noted "that Chadwick was the ultimate instrument of success was due in large measure to his rugged determination, to his humanitarianism, and to his skill as a sociologist" [16]. Flinn saw Chadwick's sociological skills in the way he allowed the facts, rather then his preconceptions, dictate the formulation of the 'sanitary idea'. Yet Chadwick was consistently cavalier in his treatment of evidence which appeared to challenge his ruling ideas $[17,18]$. Chadwick was a sociologist insofar as he had a theory of how society was held together and he developed his ideas on public health reform in dialogue with classical economy and utilitarian philosophy. Chadwick emerged with the best acceptablc argumcnts for reform and these were gradually 
adopted by much of the rest of the public health movement. These features may be highlighted by examining the writings of the public health movement on: the provision of public goods by private companies, theories of disease and the role of local government. On the first, we should notice the economic arguments employed. The second displays the importance of certain notions of the morality of nature. In all the morality of nature underwrites the morality of the market and points out the need for expert, technical solutions to environmental problems which must, therefore, place great limitations on the suitability of direct democratic control over the public health.

\section{Private enterprise and public goods}

The contemporary literature on the dirty cities was replete with criticisms of both the quality and quantity of water supplied by private enterprise to the needy citizens. In one Health Towns Association pamphlet, after the usual panegyric against the London water companies, John Liddle, living in pre-air-conditioned times, exclaimed "What a mercy it is that we are not dependent upon a public company for the supply of air!" [19]. But as Hector Gavin commented, in another pamphlet,"water, like railway companies, are trading bodies, in proposing to execute public work, they only looked for a profitable investment for their capital" [20]. Bad conditions, of themselves, conferred no right to interfere with private enterprise. The market should, it was expected, ultimately ensure through open competition that the services provided were commensurate with the need, and thus demand, for those services. Instead, the public health lobby argued that the problems they identified arose from 'abuses' of the market. Chadwick and his co-workers presented themselves as attempting to enforce the moral premises of political economy. These moral precepts were held to underwrite all economic contracts. The water companies constituted a market 'abuse' because they were incapable of fulfilling the contracts into which they had entered. Under such circumstances the government was bound to interfere. Gavin made this point explicitly after his above remarks about the profit motive:

But in order to execute these public works, they required, and obtained from the Legislature, extensive powers, privileges and immunities; it, therefore, became a duty of the Legislature, while granting these privileges, to take securities for the efficient performance of these public works. But this duty was not discharged and the powers with which these companies became invested, converted them into monopolies, under which the grievances, which I have detailed to you have sprung up $[20$, p. 49].

The public health movement saw itself as policing imperfect competition. There is an ideological continuity here with the concerns of those earlier radical 'economists' such as Joseph Hume and their attacks on 'Old Corruption'. For example, the 'Select Committee on the supply of water to the Metropolis' (1821) was principally concerned, not with documenting water quality, but with the price of water and the monopoly profits which collusion between the companies secured:

The principle of the acts under which these companies were instituted was to encourage competition: and certainly in this as in other cases, it is only from competition, or from the expectation of competition, that a perfect security can be had for a good supply; but ... from the peculiar nature of these undertakings the principle of competition requires to be guarded by particular checks and limits in its application to them, in order to render it effectual without the risk of destruction to the competing parties, and thereby of serious injury to the public [21]

In this context, a 'good' supply was primarily a cheap supply and the 'particular checks' recommended related to the restriction of price rises rather than to either the quantity or quality of the water supplied

The public health movement of the 1840 s moved beyond a concern simply with price to agitating about the quantity of water supplied but the logic of the argument was strikingly similar. It was proposed that the water companies could only fulfill their contracts, and the government discharge its supervisory obligations, if the water to be supplied was provided as cheaply and, they claimed, therefore as generally as possible. A general supply meant a constant supply at high pressure in contrast to an intermittent supply for a restricted group of subscribers. A general supply yielded lower unit costs due to scale economies and the reduction of water piracy by those not on the mains. A constant, highpressure supply was likewise attended by lower unit costs because it obviated the need for large tanks at each communal water point. In a report prepared for Chadwick's Town Improvement Company, Butler Williams claimed to demonstrate to the authorities of Bolton, Manchester and Salford that the costs of a restricted service fell most heavily upon wealthier property owners. If only two-thirds of houses rated at less than $£ 10$ per annum were subscribers and only three-quarters of those rated at more than this, then, compared with the costs of a universal system, wealthier properties would face a rate one and twothirds greater and poorer properties would face a rate increased by a half [22]. Although these figures were based on the evidence given on the Nottingham waterworks to the Health of Towns Commission and a number of objections were raised to their extrapolation to places with different topographies, Thomas Hawksley's evidence may well have been reliable at a general level since the higher unit costs of a partial system could only be passed on adequately to those consumers most able to pay, the rich [23]. Indeed, in another report for the Towns Improvement Company, P. H. Holland argued that the financial success of the Ashton-under-Lyne waterworks was because: the works were economically constructed, the running costs were very low, the company served most houses in the town, and, by having a constant supply, the company avoided the expense of providing tanks and cisterns [24].

The public health movement thus suggested that consumers had a right to low unit cost. The poor were not, in this respect, effective economic agents since, by themselves, they were unable to ensure that the companies provided cheap and general water supplies. In a pamphlet of 1847 , Thomas Southwood Smith set out a comprehensive review of these arguments:

Constant and high pressure is the most economical ... it is 
also universally applicable; and yet the public have no power to enforce its general adoption. ... If the legislature grant these [necessary] privileges and powers [to the water companies], it has the undoubted right, and it is its duty, to take securities for the due performance of the service in question. The service in the present case can be performed only on one condition, namely that the supply of water be constant and at high pressure [25].

In urging intervention in the case of the private commissions of sewers, a similar strategy was adopted. Conditions were undoudtedly bad, but to get a purchase on private enterprise, the commissions had to be convicted of transgressing the moral assumptions of economic contracts freely entered into. In St James Westminster about three-quarters of the houses examined by a 'committee of health and sanitary improvement' were found to be without 'distinct drainage' and this in an area where the Westminster Commission of Sewers had raised over half a million pounds in the previous 22 years [26]. Mismanagenent of funds was a common complaint. Of the Tower Hamlets Commission of Sewers one ratepayer from Hackney claimed that it built main sewers to which none of the inhabitants of Hackncy could afford to have a drain connected, it did not audit its collectors' accounts and, most seriously, the Commission was wasting money, $47 \%$ of its income went on management costs [27].

As with the water companies, early parliamentary attention centered on these administrative abuses rather than on the defective service provided; only one of the London commissions had an average attendance of its commissioners at business meetings of greater than one quarter and all were open to charges of jobbery [28, 29]. The parliamentary inquiries of the 1840 s more aggressively pilloried the standard of the service and the competence of the officials. The interchanges between Chadwick and Richard Kelsey, surveyor to the City Commission of Sewers, were frequently abusive and at one point Kelsey was driven to defend himself against criticisms of his sewers with the claim that he could not smell [30]. There was, however, more to the public health movement's case than this. There was Chadwick's "system of arterial drainage". In making the case against the commissions of sewers, this occupied the same position that a constant high-pressure supply of water did in the argument about the need to reform the water companies; It was the alternative system which alone could supply the service contracted for at a good price. Whatever the psychological undertones of the striving after perpetual motion implied by his scheme, and, in a letter of 1845 to Lord Francis Egerton, Chadwick explicitly spoke of being able to "realise the Egyptian type of eternity by bringing as it were the serpent's tail into the serpent's mouth", it was certainly appealingly symmetrical [13, p. 222]. Every house would be drained, and the common sewers would lead to a pumping station from which the sewer water would be pumped to the surrounding agricultural land thereby increasing the town's food supplies. The scheme aimed at "combining the advantages of town and country-conferring health on one and abundance on the other" [31]. For a working class audience it was stressed that this disproved the gloomy forecasts of Malthus:
For as it is known that there is no waste in nature, so has it also now become manifest that, but for man's ignorant wastefulness, there need be no occasion to apprehend the pressure of population upon food; the means of its reproduction being ever proportioned to the amount of its consumption, and the limit set to the numbers of mankind being regulated, not by pestilence and war, but by the power, and wisdom, and goodness of Him who 'filleth all things living with plenteousness' [32]

The similarity with the arguments about the water supply are clear. Once again, the solution reaffirmed the moral basis of free markets; there was a beneficent harmony between the ideal market situation (a chcap supply) and a socially desirable state of affairs (a good, general provision).

This benevolent harmony only held good if Chadwick could impose his system as a whole. Without improved, increased water supplies, the sewers would remain stagnant while, without the sale of liquid manure, the arterial system would be prohibitively expensive. The scheme was less practical than the proposals for improving the water supply. Morewood pointed to several problems with the details presented in the parliamentary reports and in the papers of Chadwick's second, and equally unsuccessful, excursion into private enterprise, the Metropolitan Sewage Company. First, he identified Chadwick's failure to include the costs of draining the agricultural land to be watered in his calculations. Secondly, he showed that while Chadwick proposed to transport liquid manure in sewer water, his transport costs only comprehended the movement of the liquid manure, about one-tenth of the total matter involved [33].

Although this application of sewage to agricultural land was probably the least successful aspect of Chadwick's 'sanitary idea', it was not the only source of problems. Chadwick's broad dismissal of most engineers left him open to attacks on points of detail. The Surrey and Kent Commission of Sewers was surely right to argue that he should have presented some systematic evidence on building practices before making the sweeping statements contained in the 1842 Sanitary Report [34]. In fact, as they claimed, he relied upon John Roe (the surveyor to the Holborn and Finbury Commission) for his information on the practices of the several metropolitan commissions. The Westminster Commission complained that:

The truth is evident, that the Secretary of the Poor Law Commission has been content to inform himself in respect of the Metropolitan sewage by special deference to the opinion of one individual, whose object has been to give himself importance by vaunting his own contrivances, by exalting his own commission, exaggerating his own success, and with unbecoming boldness casting unjust reflections on the adjoining commissions, traducing the competency of his brother surveyors of the surrounding jurisdictions [35].

In his eagerness to condemn prevailing building practices, he implied that Roe was the only metropolitan engineer to build his sewers with the more efficient curved rather than flat floors. Chadwick's favoured rounded bottoms had been a feature of new sewers in the Westminster Commission through the previous 50 years and the City Commission claimed that flat-bottomed sewers were a legacy from the past and were now in a minority in the City $[35, p .14 ; 36]$.

If we are to understand why the public health 
movement seemed so impatient with contradictory details and why it did not simply document the appalling environmental conditions in making a case for public health reform, then, we need to see the logic of their consistent programme, their continuous chain of reasoning. The first links in the chain were propositions central to, rather than in conflict with, the veneration of private property. Some of the later links were of a more scientific or technical character. In this area, there was, in Chadwick's view a problem of communication. These were not matters on which the ignorant could sensibly be asked to decide. The claim that matters of expertise should be passed down for implementation rather than evaluation and the conviction that such matters lay at the heart of the sanitary idea, led Chadwick to a very specific view of the obstacles to sanitary improvement at a local level.

\section{Parochial authorities}

In many ways, the public health movement convicted parochial authorities of the same inefficiency, jobbery and ignorance that it saw as characteristic of other unreformed bodies like the water companies and commissions of sewers. Local autonomy was dear to the Victorian bourgeoisie. It signified the political sway of propertied classes and independence from central tyranny by being the control of a community by its local propertied elite. Public health reform inevitably presented a potential threat to that autonomy by imposing a new set of responsibilities on property without allowing local ruling groups the right to veto those qualifications. The links between knowledge and centralisation were contingent upon restricting the ability of parochial authorities to improvise solutions to the problems with which they were faced.

This strategy of containment with its attendant elevation of the expert as a centralising focus is quite evident in the publications of the public health movement but it is clearest in the publications of the General Board of Health on the lessons of the cholera epidemic of 1848-9. The problems faced at a local level were analysed almost solely in terms of the difficulties the General Board had in getting them to follow its instructions. Two major problems admitted by the Board were the fact that the poor law authorities had taken a rather narrow view of their responsibilities and, secondly, that too many local authorities were not yet fully aware of the irresistible case for sanitary activity. With regard to the preventive measures urged by the General Board, it was noted that:

The provision intended by the legislature was one for the common protection against impending dangers, as has been stated to all classes, against which the individual means of private persons were inadequate. But the common functions of the Poor-Law Guardians related exclusively to one class, the destitute or pauper class only. Notwithstanding the scope of the Act, and explanatory notifications, the first and common impression of the guardians of the poor was, to confine the measures of prevention to the destitute, and administer it according to their settled practice, as respects the relief of paupers, which is to do nothing except on application, and then only upon proof given of the urgency of the case [37].
This effectively meant that the public health authority only saw patients when they were in a state of collapse. The guiding principle of the 'sanitary idea' was that prevention would be cheaper and more effective then cure. In general, the central authority found that it could encourage the willing but not coerce the reluctant authorities. Chadwick put this down to the incomplete diffusion of the proofs of the sanitary idea:

The chief obstacles to the general and early adoption of measures of prevention arise from the difficulty of communicating to those whom it is necessary to convince. such information as may satisfy their minds of the incomparable greater efficacy of measures of prevention than of those that are merely paliiative or curative $[37, \mathrm{p} .148]$.

What Chadwick omitted to discuss were the problems posed by the local opposition to the 1834 Poor Law Amendment Act. Local poor law authorities were still, in many cases, actively resisting control by the central Poor Law Board. Certainly in terms of central-local relations, the decision to work through the poor law boards of guardians put many places beyond the direct control of the General Board. In London, as late as 1867 one third of the area was "being regulated by local Acts that made the parishes independent of control by the Poor Law Board" [38].

To understand why, despite these difficulties, Chadwick continued to insist that the poor law unions were the appropriate 'modern' authorities through which public health activity should be directed, that greater central control was required and that the experience of 1848-9 underlined these points, we must remember how important a part administrative structures played in the public health propaganda. In 1842 Chadwick wrote of the 1831-2 cholera epidemic that:

The nuisances which favoured the introduction and spread of the cholera were for the most part within the cognisance of the Leets [manorial local authorities], and could not have existed had their powers been properly exercised, yet so complete was the desuetude of the machinery of these courts that it appeared nowhere to be thought of as applicable, and the new and special machinery of the Boards of Health were created for the purpose of meeting the pestilence $[16$, p. 360].

With existing bodies inadequate, Chadwick proposed investing these abandoned powers in the poor law unions; the prevention of disease would be in their interest as this would reduce the number of sick on the poor rates:

When the extent of the removable causes of sickness and mortality are more clearly and extensively understood, as they will be, the Boards of Guardians will of necessity occupy much of the position of the Leet, as a body fitted to act on complaints made, and to reclaim the execution of the law against omissions and infractions which occasion illness or injury to the most helpless classes $[16$, p. 396].

Equally important, for Chadwick, was the fact that the poor law unions were supposed to be subject to some form of central direction and inspection and might appoint officers who were beyond the influence of petty and sinister interests' by being accountable to a central authority rather than just local patronage or politics [38]. 
Chadwick was a fanatical centraliser. Lyon Playfair noticed his dogmatism on this point:

I recollect, on one occasion, trying to argue with him as to the need of throwing greater responsibility on localities, and lessening the functions of central government so as to make them supervisory rather than administrative. My arguments were met with this stern rejoinder-'Sir, the Devil was expelled from heaven because he objected to centralisation, and all those who object to centralisation oppose it on devilish grounds!' [39].

Chadwick saw the New Poor Law as a vehicle for 'expert', centralised government which alone would allow the full implementation of his 'sanitary idea'. $\mathrm{He}$ argued that the obstacles to effective measures at a local level were a lack of strong, correct, central direction rather than, say, the inability of parochial authorities to force water companies, commissions of sewers and landlords to improve the living conditions of the poor. Expert knowledge was, he believed, a scarce commodity which was more efficiently deployed by central direction than by entrusting scientific questions to uninformed local representative bodies. To sustain the claim that imperfections in the market needed proper policing and that this policing was properly the job of technical experts, required centralisation as an appropriate vehicle of correct technology but also explicitly confronted prevailing notions of the responsibilities and local representation of property. This was supportable only so long as the new technology was grafted onto an even deeper sense of the morality of private property than was threatened by the attack on local autonomy. In other words, a balance had to be struck between, on one hand, seeing central intervention as the only way to get the expert control of the evironment thought to be required and, on the other, directly attacking the integrity of local property owners with their independent local authorities. This new technology needed more to recommend it than the say-so of Chadwick's chosen engineers. Chadwick achieved this by returning to environmentalist theories of disease and recovering from them a statement about the moral and divine purpose in nature. If he could link his sanitary engineering to a theory of disease which brought in the support of referring to God's plan-for-the-world in natural design, then, local opposition to the new technology could be presented as flouting the laws of nature.

\section{Theories of disease}

The morality of the market was, to Chadwick, a natural phenomenon. In other words, it rested on natural forces and replicated the morality of nature. Natural phenomena were not seen as ethically neutral. In their study of urban mortality, the public health reformers tried to tie the behaviour of diseases such as cholera to a world view in which they made sense as a prompter of the 'sanitary idea'. For our purposes, what is significant is the conviction among the public health pressure group that in certain ways the aetiology of epidemic disease underlined the sorts of conclusions they drew about the moral basis of the 'sanitary idea'. To this extent, the fact that in medical circles a more open and empirical approach was adopted is to be seen as a contrast to, rather than a basis for, the confident anticontagionism of leading public health campaigners $[18,40,41,42]$. Public health is pre-eminently about the interaction between the natural and social worlds. If Chadwick had certain beliefs about the natural harmony of the market, then, he was driven, in this area, to allow the natural world either to reinforce or to confound that harmony. In fact he believed the former, as did many of his colleagues. If it is conceded that in their theories of disease transmission, their complete world view was at stake, then, the tenacity with which they clung to anticontagionism becomes understandable.

In examining how public health reformers treated the subject of disease transmission, two departures from what one might regard as scientific best practice' stand out. First, the tendency to see the robustness of any proposition in terms of how it gelled with a consistent world view rather than in terms of the balance of evidence for the proposition considered on its own. Secondly, a tendency to see if the proposition was consistent with various facts rather than attempting to set it up in a form inviting falsification. This second characteristic often led to the use of facts as illustrations rather than tests of various propositions. Chadwick epitomised both of these features. In parliamentary reports he thundered on about the non-contagious nature of cholera and in the papers of the General Board of Health he maintained that the epidemic of 1848-9 had not shaken the truth of this theory.

Chadwick worked with Southwood Smith and Richard Owen on the Metropolitan Sanitary Commission. Southwood Smith probably first drew Chadwick's attention to the significance of the noncontagiousness of diseases capable of assuming epidemic dimensions. Owen was a leading physiologist whose views on this matter matched Chadwick's. In the First Report of the Metropolitan Sanitary Commission, they claimed that "there is no evidence that cholera spreads by communication of the infected with the healthy" [43]. The empirical basis of contrary arguments was devalued by stating that "suddenness of attack is apparent only, and not real" [44]. They suggested that cholera was invariably preceded by a stage of premonitory diarrhoea so that the disease could be developing within a person well before its peculiar distinguishing features appeared. It was, therefore, impossible to infer a sequence of disease contraction from a series of deaths or even a series of conventionally-defined attacks. The clustering of attacks in time and space were the features to which contagionists drew attention. On this anticontagionist reasoning, the clustering in time could not be reliably identified and the clustering in space was due to the lpcalisation of environmental defects, primarily the piles of decomposing filth which were thought to induce diseases such as cholera.

While the medical debates negotiated evidence contradicting the anticontagionist case by developing a theory of contingent contagionism specifying the special circumstances under which a disease such as cholera might become epidemic and contagious, Chadwick and his colleagues tried to explain away this contradictory evidence by sticking to anticontagionist theory and setting out the predisposing and efficient causes of cholera which might, under certain conditions, lead the disease to display a 
spatial concentration giving the appearance of contagiousness. Predisposing causes selected individuals by their congenital defects or their poverty. They were of very limited significance, suggested the anticontagionists, and little could be done about them Far more important were the efficient causes which were environmental:

These physical causes of disease may affect various localities and different classes of persons, but are most common and virulent in the neglected districts and dwellings of the poor. who are peculiarly exposed to the aggravating influences of such causes-not necessarily connected with their condition in life, but capable of being removed by efficient drainage, cleansing, improvements of buildings, ventilation and a sufficient supply of good water. It is too commonly supposed that the evils above adverted to are the inseparable concomitants of poverty ... [45].

After the 1848-9 epidemic, the general Board of Health concluded that its ideas had been completely vindicated. However, it had been widely argued by others that those who attended the sick were at greater risk of catching cholera and that contagious spread must take place in these cases. Indeed, several registrars had noted such circumstances on their death returns, some of which were cited in contemporary newspapers [46]. The General Board acknowlcdged that "several alleged facts were recorded in the Registrar-General's Returns, with reference to the metropolis" $[37$, p. 18]. The notion of predisposing and efficient causes was then used to explain away these alleged facts and to effectively place the anticontagionist theory beyond empirical falsification. In line with this theory the medical practitioner selected by Southwood Smith to investigate allegations that washerwomen attending on cholera cases had caught the disease from dirty linen found that "not a single case can be proved to be owing to contagion" and in all cases:

The attack can be at least as well assigned to other causes as to the alleged one. In one case I ascertained that the deceased did not wash the infected clothes, while the person who did escaped. In three others, at least, the disease manifested itself before the linen was washed. In nearly every instance the condition of the house and the street or court inhabited by the patient was of the most dangerous condition [37, p. 34].

Only the ten cases where the registrars had suggested that the washerwomen had caught the disease from infected bed linen were investigated; the cholera mortality for this occupational group as a whole was not considered. More seriously, to restrict the proof of contagionism to cases where no other factors at all could have operated was hardly even-handed. This special pleading is even clearer in the General Board's discussion of the mortality of nurses:

We made a careful examination into all the cases that were brought under our notice, in which nurses were reported to have caught the disease from a close attendance on an infected person. In every case thus investigated, we found either that the nurse had been previously suffering under premonitory diarrhoea, in some cases for several days together, which she had neglected, or that she had committed some act of intemperance, or was exhausted by overfatigue; predisposing causes [of] ... powerful influence [47]

Note here that no consideration is given to the possibility of the premonitory diarrhoea having been contracted during attendance on some earlier cholera case and note too that in the midst of an epidemic the theory of contagion cannot be established in the case of tired nurses. Chadwick consistently refused to acknowledge a theory of contingent contagionism, the idea that under certain circumstances the disease could become contagious. For him, the contagionists had to claim that contagion was the only way that cholera could spread and also that given the presence of infected people its spread was inevitable. On his reading the contagionists needed, therefore, to believe that the disease would advance in a continuous and regular way, in which case they were wrong "there being in general no regular continuity in its course, but its progress consisting in a succession of local outbreaks" [37, pp. 34-35]. Furthermore, he noted that "in numerous instances individuals arrived in uninfected localities with the disease upon them, and died without communicating the infection to anyone, and without the spread of the disease" [37, p. 33].

This special pleading allowed Chadwick and his colleagues to conclude that the anticontagionist theory explained all the known facts. It had a systematic grasp of reality and was, therefore, suggestive of correct policies. Thus Florence Nightingale insisted in a letter to William Farr: "Quarantine follows logically and inevitably on "contagion"-as Sanitary measures on "non-contagion" [48]. Indeed, it was the possibility that William Pym, at the Privy Council, might declare a quarantine in the event of cholera returning to Europe that led Chadwick to devote most of the Second Report of the Metropolitan Sanitary Commission to articulating the anticontagionist case. He was thoroughly disgusted when Pym announced a quarantine anyway and he complained that "the results of the enquiry aided by the first physiologist in Europe, Professor Owen, the recommendations of the General Board of Health were set at nought, suddenly, summarily, without the slightest notice given or reason assigned" [49]. Chadwick clearly believed that his "sanitary idea' had the imprimatur of Nature and anticontagionism was important in this regard. Through a number of seemingly independent channels he established anticontagionism as the official doctrine in opposition to the more sophisticated medical theory of contingent contagionism. His theory of disease provided important support for his environmentalist public health strategy. It was integral to the linking of nature, morals and markets in one continuous chain of reasoning which, as a whole, was more powerful than the sum of its individual parts.

\section{THE 'SANITARY IDEA' AS IDEOLOGY}

Therborn usefully suggests that ideologies orient people in their worlds in at least three ways: by telling people what exists; by telling them"what is possible, providing varying types and quantities of selfconfidence and ambition, and different levels of aspiration"; and by telling them"what is right and wrong, good and bad" [50]. It would appear that the "sanitary idea' functioned in each of these three ways. These sorts of ideas do not float free of particular social contexts and here again Therborn has some 
helpful observations in speaking of the way the implementation of ideologies is either affirmed or sanctioned by the context in which they are applied. Affirmation occurs if, when someone "acts in accordance with the dictates of ideological discourse, then the outcome predicted by ideology occurs". Alternative views of the possible and the good mesh with, in the case of environmental management, prevailing power structures when competing ideologies are followed: "If every ideology operates within a matrix of affirmations and sanctions, then the competition, coexistence or conflict of different ideologies is dependent on the non-discursive matrices. The power of a given ideology in relation to others is determined by its pertinent affirmations and sanctions" [51]. The 'sanitary idea' described the links between society, nature and markets in ways that defined the prospects and justification for sanitary engineering directed by the expert advice of central government. The relevant affirmations and sanctions included the technological requirements of healthy urban living but they also included less technical issues such as a sanctity of property, the constitutional significance of autonomous local government as a check on arbitrary central power, and the professional pretensions of established civil engineers whose work was held up to ridicule by Chadwick. Some of these forces acted in all fields of government growth while others were specific to public health reform

There are close links between ideas and power, as Corrigan and Sayer note in speaking of "the three great 'ideas' which energised the system of national improvement that was state formation in this period [the mid-nineteenth century] - the twin faces of 'the statistical idea' and 'the educational idea', and the much more subordinated (for it too much challenged local powers) 'sanitary idea'..." $[12$, p. 129]. The 'sanitary idea' contended on one hand with the rights of property and on the other with the need for effective legislation. If the latter could have been secured without offence to the former then Chadwick, an astute tactician, would undoubtedly have taken the more persuasive course. In the early 1840 s there were those who believed that a milder course would actually work. Among them was Robert Slaney, and Richards has drawn attention to "one vital difference between Slaney's plan and the Benthamite [Chadwick's] model ... the balance of power was to be with local and not central government" [52]. What Chadwick achieved between 1842 and 1847 was to convince enough people favourable to reform that there was a contradiction between advocating effective national minimum standards and expecting to proceed by waiting upon local initiative. In this he was right. When Chadwick was removed from the General Board of Health, his successor was an arch localist, Benjamin Hall. A representative of London vestrydom, he was initially disposed to rely upon local initiative in solving London's problems of drainage, sewerage and water supply. Nevertheless he soon "discovered that a laissez-faire policy simply would not answer and that central government must act positively" [53]. In short, Chadwick set up the best arguments with which to counter apathy, obstruction and outright opposition

Chadwick's best arguments had to move beyond mere journalism. The public health agitation was politically and ideologically structured by the need to counter the claim that it was undermining the rights of property. Just as journalists who expect certain lines of censorship may end up censoring and restricting their own lines of investigation, so the public health reformers internalised the need to respect private property, an institution which they had no wish to overthrow. Consequently, they appealed to the most advanced defence of legislative interference within the framework of private property: Chadwick's version of philosophic radicalism. The sort of abstract defence if the market propounded in the writings of Bentham and associated philosophers and economists, allowed Chadwick to distance his attack on current market practices from a heretical denigration of capitalism as it was worshipped. He separated the ideal from the reality. The ideal was a market consisting entirely of petty commodity producers. The reality of speculation, monopolies and excess profits fell outside this ideal of individualistic production and consumption. This strategy provided a continuity between the arguments of Joseph Hume in the early-nineteenth century and those of the much less radical Lord Morpeth in the 1840s. Morpeth's commitment to this manoeuvre was clear in the way he defended himself against the charge that his Drainage of Towns Bill constituted an attack on private property. On the contrary, he argued, "speculators made exorbitant profits from the working classes being obliged to dwell in certain localities. It was these profits he meant to reduce" [54]. This lack of choice on the part of the poor undermined one of the assumptions under which a free market could be expected to produce equity;

It is, therefore, a mistake to say that the poor are free agents in this respect: the fact is, that this necessity on the part of the poor gives the proprietors of these loathesome dens a command of the most he can by any means in his power, extort from his tenants [55]

Classical political economy was based on a series of moral precepts which sustained the 'lessons' it drew from the 'working' of the market. Perhaps the central term in this cosmology was 'harmony'-a reconciliation of the 'individual' and the 'social', the 'short-term' and the 'long-term'. Nature ensured a harmony between the short-term pursuit of rational self-interest and the long-term welfare of both individual and society. If everyone behaved selfishly, nature would reward those who had behaved in a rational manner and punish those who had not. The anticontagionism of Chadwick and his associates was, in part, a defence of a conception of Nature as both loving parent and benevolent school-teacher. As MacLaren argues, disease, and especially capricious epidemic disease, posed problems for this view of things [56]. The difficulty was that even if failure to comply with the dictates of natural law always led to suffering, need it be conceded that much suffering could arise in quite different ways, by chance encounters or whatever? It was difficult to see epidemic disease as the realisation of long-term processes unless the disease took advantage of failings that had already taken place.

To retain their belief in the harmony between 
natural (long-term) law and the (short-term) pursuit of rational self-interest, the public health agitators who took their cue from Chadwick had to believe that disease behaved in a rational manner. Cholera had to be tied to earlier actions. This explains their preference for a theory incorporating predisposing and efficient causes instead of one based on contingent contagionism. The idea of predisposing and efficient causes linked the immediate threat of disease both to environmental conditions and to earlier individual acts of intemperance or stupidity. The stochastic nature of contagionism threatened to place cholera beyond the workings of this natural harmony. Under the regimen of predisposing and efficient causes, non-contagious cholera did not blindly shatter the fabric of nature, rather it worked along lines of previous weakness.

Chadwick's arguments about political and administrative structures need to be seen in a similar light. From Hobbes, the philosophic radicals developed a conception of the State as the artificial identification of interests. The State was expected to provide the context within which the rational pursuit of selfinterest could harmonise with natural law. Social engineering, however, was not compatible with direct democracy since the ability to decide upon 'scientific' questions was not widespread and also we must remember that Chadwick and many of his fellowworkers were professionals (lawyers, doctors, engineers) at a time when the landed classes were only starting to share power with this wider ruling class so that an element of self-interest was also involved. In order to ensure the expert identification of rational interests, social reform needed to be removed from the vagaries of 'popular' politics. Chadwick wanted to take technical questions out of the sphere of local politics altogether, and he even hoped to maintain a discrete distance from Parliament. As Corrigan comments, "the form of state surveillance and administration which Chadwick seemed to admire ... was parallel to Parliament, a series of standing commissions linked to the Privy Council" [57]. In line with this prejudice, Chadwick convicted the local authorities of ignorance and inertia.

Turning to the sociological question of what holds society together, the Benthamite response was primarily psychological. Bentham saw society as the summary result of individual motivations. Social policy must aim at directing these impulses. The psychology of the individual was crucial to the use of the felicific calculus. In the abstract, social policy should, according to Bentham, be directed towards maximising the sum of individual happinesses. In practice, this rested on the specification of the 'springs of happiness':

Bentham knew that the principle of the greatest happiness of the greatest number as the proper end of government was too general to be of much use in concrete cases. Accordingly he proposed that specific determinations should be made in the light of what he called the four subsidiary ends of legislation: security, subsistence, abundance and equality [58].

To operationalise this specification, he satisfied himself that security, and particularly security of property, was the primary end of government: "without some assurance that property will be protected, people would make little or no effect to create new wealth. The principal object of the law is, therefore, to take care of security for, in doing so, the other ends will be served as well" $[58$, p. 68$]$.

By making this defence of property central to their political theory, Benthamites could advocate reforms in ways which took cognisance of the dominant worry that reforms threatened the rights of individuals to enjoy the full fruits flowing from private ownership. It explains why the public health movement couched its attacks on the water companies and commissions of sewer in terms of a championing of the morality of the market-the precepts of political economy. They had to convict these enterprises of mismanagement, propose alternative arrangements and show that these alternatives were necessary in market terms-only under these arrangements could the companies fulfil the obligations, as well as exploit the rights, of private property and provide a good, cheap service. This led Chadwick to assert that the principles of scientific sanitation were quite beyond the ken of the existing companies, residing solely with the public health movement itself. In all Chadwick had to convince himself and others that existing bodies were incompetent rather than impotent in order to justify the idea of expert control.

Private property was the crucial political and ideological bloc to public health reform. The fact that the arguments for reform were developed in the way outlined above underlines the nature of the ideological battle that was fought. If pragmatic, sensible reforms would inevitably, eventually have been adopted, then, there is little evidence of that here. Given a straight choice between the general health and the individual property, the prospects for reform were so bleak that the choice had to be avoided and the distinction subverted. In this respect, the more dramatic events such as cholera and typhus epidemics which might have been expected to clinch the case for reform if the major requirement was good journalism, needed to be treated very carefully by the reformers if the sophisticated intellectual case they were making was to be listened to. Repeated epidemics or scares might jade the public palate while the fact that epidemics came and went made it difficult to sustain the case that the problems were continuously present. What is striking is the success of the public health arguments in the 1840 s. Starting from a defence of the market and a celebration of the moral duties of private property, Chadwick succeeded in convincing the public opinion to which parliamentarians felt answerable that the major obstacles to improvement were vested interests. Between 1848 and 1854, the General Board of Health became tarred with the same brush and the water companies and private landlords had their revenge. On the back of claims that Chadwick's General Board of Health existed simply to promote the careers of certain favoured sanitary engineers, the representatives of the London water companies secured Chadwick's dismissal from public life. For these vested interests, the defence of private property was the defence of a livelihood, a defence of an economic structure. In fact, the economic structure was not overthrown, it was manipulated within a range of constraints that increasing prosperity loosened a little with time. The 
opposition of landlords and the poverty of tenants provided the background to a guerilla war between private property and public health reforms.

There is a broad range of interpretations of the forces impelling and constraining government growth in the nineteenth century. The polar opposites may be characterised as the pragmatic and the ideological explanations [59]. The former emphasises the reasonable, gradual adoption of reforms shown to be necessary by the social problems accompanying rapid urban-industrialisation. The political system is seen to be an automatic regulator of society matching perceived social needs to effective legislation. The obstacles to reform, on this reading, are ignorance and the sheer scale of the problems. In contrast, the ideological school lays stress on a new idea in the growth of government, a new positive role for government deriving from the schemes for legal reform systematically developed by Jeremy Bentham, the utilitarian philosopher, in the late-eighteenth century. Whereas under the pragmatic explanation ideas are of marginal significance, here they are the very content of the legislative principle. The emphasis in this paper on the need for a fairly sophisticated 'sanitary idea' in presenting the case for reform is incompatible with the pragmatic approach, epitomised in this field by the works of Cherry and Ashworth $[60,61]$. The political significance of these historiographical disputes is roughly captured by Hart's identification of the pragmatic approach as a "Tory' interpretation of history [62]. Within the ideological approach there is a degree of uncertainty about the relations between Benthamite programmes and broader social and political forces. In reconstructing the logic of these arguments in one particular area, public health reform, this paper has shown how great were the efforts made to keep the case for reform within the ideological parameters set by a commitment to bourgeois property rights. In effect, though, small-scale landlord property was politically marginalised by Chadwick's appcal to the need for the state to police market imperfections and, by making local government finance the vehicle for social reform, nineteenthcentury government growth marginalised this group economically too. The fundamental economic forces behind the battle of ideas continually reasserted themselves leading eventually to the bankruptcy of the rented sector in English cities and the need for public housing to step into the breach, perhaps only temporarily.

\section{REFERENCES}

1. Henriques U. Before the Welfare State: Social Adminis tration in Early Industrial Britain, p. 117. Longmans, London, 1979.

2. Bruce M. Introduction. In The Rise of the Welfare State: English Social Policy 1601-1971 (Edited by Bruce M.), p. 10. Weidenfeld \& Nicolson, London, 1973.

3. O'Riordan T. Environmentalism, pp. 19-20. Pion Books, London, 1976.

4. Tatham G. Environmentalism and possibilism. In Geography in the Twentieth Century: A Study of Growth, Fields, Techniques, Aims and Trends (Edited by Taylor T. G.), p. 128. Methuen, London, 1951

5. Hardy A. Water and the search for public health in London in the eighteenth and nineteenth centuries. Med. Hist. 28, 269, 1984.
6. Offer A. Property and Politics, 1870-1914: Land Ownership, Law, Ideology and Urban Development in England. Cambridge University Press, 1981

7. Swenarton M. Homes Fit For Heroes: The Politics and Architecture of Early State Housing in Britain. Heincmann Educational. London, 1981.

8. Brayshay $M$. and Pointon V. Local politics and public health in mid-nineteenth-century Plymouth. Med. Hist. 27, 32, 1983.

9. Pollard S. A History of Labour in Sheffield. Liverpool University Press, 1951.

10. Kearns $G$. Nuisances, cholera and environmental regulation: Islington 1830-55. In Living and Dying in London 1500-1900 (Edited by Bynum W. F.). Croom Helm. London, 1987.

11. Vigier F. Change and Apathy: Liverpool and Manchester During the Industrial Revolution. M.I.T. Press, Cambridge, Mass., 1970.

12. Corrigan P. and Sayer D. The Great Arch: English State Formation as Cultural Revolution, p. 116. Blackwell, Oxford, 1985.

13. Finer S. E. The Life and Times of Sir Edwin Chadwick. p. 351. Methuen, London, 1952.

14. Islington Public Library, Y.L. 385/98387-407, St Mary Islington, Trustees of St Mary Islington, Minutes 1824-66, 29th March 1848.

15. British Parliamentary Papers [hereafter P.P.] [854-5 (244) xiii, p. 413 Report of the Select Committee on the Public Health Bill and Nuisances Removal Amendment Bill, q469, 70, p. 5.

16. Flinn M. W. Introduction. In Report on the Sanitary Condition of the Labouring Population of Gt Britain by Edwin Chadwick 1842 (Edited by Flinn M. W.). pp. 35-36. Edinburgh University Press, 1965.

17. Blaug $M$. The Poor Law Report re-examined. J. econ Hist. 24, 229, 1964.

18. Kearns G. The cholera test and nineteenth-century Britain. University of Liverpool, Department of Geography Working Paper 20, 1986.

19. Liddle J. On the Moral and Physical Evils Resulting from the Neglect of Sanitary Measures, p. 16. Health of Towns Association, London, 1847.

20. Gavin H. Unhealthiness of London and the Necessity of Remedial Measures, pp. 48-49. Chadwick. London, 1847.

21. P.P. 1821 (537) v, p. 21 Report of the Select Committee on the Supply of Water to the Metropolis, p. 5.

22. British Library CT 456-4 Draft Report of Butler Williams, Esq. On the Improvement of Bolton, Manchester and Salford. p. 29. Unpublished Towns Improvement Company report, 1845.

23. Wickstead T. Analysis of Evidence in Favour of the Constant Supply. Weale, London, 1846.

24. Holland P. H. Report on the Ashton-under-Lyne Water Works, p. 6. Towns Improvement Company, London. 1846.

25. Southwood Smith T. Report of Committee to the Members of the [Health of towns] Association on Lord Lincoln's Sewerage, Drainage etc. of Towns Bill, pp. 61-62. Knight, London, 1847.

26. St James Westminster Committee of Health and Sanitary Improvement. Report of the Proceedings of the Committee upon the Inquiries Made by the Visitors as to the Sanitary Condition of Certain Districts of the Parish, p. 12. Vestry of St James Westminster, London. 1848.

27. A Parishioner. A Letter to the Parishioners of Hackney upon the Subject of the Sewers Rate; and the Drainage Bill Recently Introduced into Parliament by the Marquis of Normanby, pp. 14-15. J. Masters Edmund Fry Caleb Turner, London, 1841

28. P.P. 1823 (542) v, p. 1 Report from the Select Committee appointed to inquire into the powers vested in 
and exercised by the commissioners of sewers in the metropolis.

29. P.P. 1834 (584) xv, p. 197 Report from the Select Committee appointed to inquire into the state of the law respecting sewers in and near the Metropolis.

30. Health of Towns Association. The Sanitary Condition of London, p. 8. Health of Towns Association, London, 1848.

31. The Metropolitan Working Classes' Association for Improving the Public Health. Drainage and Sewerage, p. 16. John Churchill, London, 1847.

32. Health of Towns Association. Address from the Committee of the Health of Towns Association to the Reverend The Bishop of London and the Reverend Clergy, p. 4. Health of Towns Association, London, 1848.

33. Morewood J. J. Letter ... to Lord John Russell on Drainage .. and the State of the Thames, pp. 10-11. London, 1846.

34. Greater London Record Office SKCS 919, Surrey and Kent Commission of Sewers. Reports relating to the sewerage with reference to the observations of the Poor Law Commissioners in the Inquiry into the Sanitary Condition of the Labouring Population of Great Britain, p. 6. Unpublished Surrey and Kent Commission of Sewers report, 1843.

35. Donaldson T. L. Address upon the Report from the Poor Law Commissioners in Reference to These parts Which Inculpate the Metropolitan Commissions of Sewers, p. 30. Westminster Commission of Sewers, London, 1842 .

36. Kelsey R. Surveyor's Report as to the main Lines of Sewer within the City of London, the Mode of Junction, Sectional Form, Gullies and Ventilation, p. 45. City Commission of Sewers, London, 1842

37. P.P. 1850 [1273] xxi, p. 3. Report from the General Board of Health on the Epidemic Cholera of 1848 and 1849 , p. 138.

38. Brown W. G. The St. Pancras Poor: A Brief Record of Their Treatment, 1718-1904, p. 26. Metropolitan Borough of St Pancras, London, 1905.

39. Memoirs and Correspondence of Lyon Playfair (Edited by Reid T. W.), p. 64. Casell, London, 1899.

40. Ackernecht E. H. Anticontagionism between 1821 and 1861. Bull. Hist. Med. 22, 562, 1948.

41. Pelling M. Cholera, Fever and English Medicine 1825-1865. Oxford University Press, 1978

42. Cooter R. Anticontagionism and history's medical record. In The Problem of Medical Knowledge (Edited by Wright P. and Teacher A.), p. 87. Edinburgh University Press, 1982

43. P.P. 1847-8 [888] [895] xxxii, p. 1, p. 57 First Report of the Commissioners appointed to inquire whether any and what special measures may be requisite for the Improvement of the Metropolis, p. 7.
44. P.P. 1847--8 [911] [921] xxxii, p. 253, p. 293. Second Report of the Commissioners appointed to inquire whether any and what special measures may be requisite for the Improvement of the Metropolis, p. 9.

45. P.P. 1845 [602] xviii, p. 299 Second Report of the Commissioners for inquiring into the State of Large Towns and Populous Districts, pp. 3-4.

46. Kearns G. Historical Geography and Urban Epidemics: Cholera in London 1848-9. Geobooks. Norwich. 1985.

47. P.P. 1850 [1275] xxi, p. 367. Appendix B to the Report of the General Board of Health on the Epidemic Cholera of 1848 and 1849. Report of $\mathrm{Mr}_{\mathrm{r}}$ Grainger, pp. 186-718.

48. Eyler J. Victorian Social Medicine: The Ideas and Methods of William Farr, p. 188. John Hopkins University Press, Baltimore, Md, 1979.

49. University College London. Manuscripts. Chadwick Collection MSS 57. Notes on the Privy Council Administration of Quarantine in the Towns.

50. Therborn G. What Does the Ruling Class Do When it Rules?; p. 172. New Left Books, London, 1978.

51. Therborn G. The Power of Ideology and the Ideology of Power, pp. 34-35. New Left Books, London, 1980.

52. Richards P. R. A. Slaney, the industrial town and early Victorian social policy. Soc. Hist. 4, 92, 1979.

53. Owen D. The Government of Victorian London 1855-1889: the Metropolitan Board of Works, the Vestries and the City Corporation, p. 31. Harvard University Press, Cambridge, Mass., 1982.

54. Hansard's Parliamentary Debates. Third Series, Vol. 60 , House of Lords, 10th February 1842, col. 240.

55. Hansard's Parliamentary Debates. Third Series, Vol. 76, House of Lords, 26th July 1844, col. 1467.

56. MacLaren A. A. Bourgeois ideology and Victorian philanthropy: the contradictions of cholera. In Social Class in Scotland: Past and Present (Edited by MacLaren A. A.), p. 36. Donald, Edinburgh, 1976.

57. Corrigan P. State formation and moral regulation in nineteenth-century Britain: same sociological investigations, p. 278. Unpublished Ph.D. thesis, Durham, 1977.

58. Steintrager J. Bentham, p. 67. Allen \& Unwin, London, 1977.

59. Revolution or Evolution: British Government in the Nineteenth Century (Edited by Cromwell V.). Longmans, London, 1977.

60. Cherry G. Urban Change and Planning: A History of Urban Development in Britain Since 1750. Foulis, Henley-on-Thames, 1972.

61. Ashworth W. The Genesis of Modern British Town Planning: A Study in Economic and Social History of the Nineteenth and Twentieth Centuries. Routledge \& Kegan Paul, London, 1954.

62. Hart J. Nineteenth-century social reform: a Tory interpretation of history. Past \& Present 31, 38, 1965. 